\title{
The rate of heat loss during fasting in the growing pig
}

\author{
By W. H. CLOSE aNd L. E. MOUNT \\ ARC Institute of Animal Physiology, Babraham, Cambridge CB2 ${ }_{4} A T$ \\ (Received 2 fanuary 1975 - Accepted I7 March 1975)
}

\begin{abstract}
I. The heat loss for individual growing pigs, whose initial body-weight was $25-40 \mathrm{~kg}$, was measured continuously for periods of 14 or $21 \mathrm{~d}$ when they were maintained at an environmental temperature of either 20 or $30^{\circ}$. For each temperature the feeding level before and after a period of fasting was held at either 39 or $45 \mathrm{~g} / \mathrm{kg}$ body-weight per d. Four pigs were given each treatment; food was withheld from three animals for a $4 \mathrm{~d}$ period in each experiment, and the fourth pig (control) was fed for the whole experimental period.

2. After the withdrawal of food, the heat loss decreased rapidly and minimum values were recorded during the third and fourth days of fasting. Fasting heat loss was higher at $20^{\circ}$ than at $30^{\circ}$ and was not significantly dependent on the preceding level of feeding. The mean values obtained at 20 and $30^{\circ}$ were 457 and $380 \mathrm{~kJ} / \mathrm{kg}^{0.75}$ per d respectively.

3. The heat loss during the periods of feeding was significantly higher $(P<0.05)$ at $30^{\circ}$ than at $20^{\circ}$, and was also higher at the higher level of feeding.

4. The apparent efficiency of utilization of metabolizable energy for maintenance was calculated as 0.80 .

5. It was concluded that the critical temperature for a fasting pig weighing $25-40 \mathrm{~kg}$ is approximately $\mathbf{2 5 ^ { \circ }}$.
\end{abstract}

The energy for fasting metabolism is derived from body stores, so that the fasting metabolic rate equals the rate of energy loss from the body. When the animal is fed at the maintenance level of intake, there is no net loss or retention of energy because the metabolic rate equals the energy intake. The ratio, minimal fasting metabolism: minimal maintenance metabolism then gives the efficiency with which the energy intake is used for the animal's maintenance. This is distinct from the partial efficiency with which the excess energy intake over the maintenance level of intake is retained.

The term 'minimal metabolism' refers to the metabolic rate above the critical temperature, but within the zone of thermal neutrality, for a given level of feeding, and is in this way distinct from 'basal metabolism'. The critical temperature is defined as the environmental temperature at the lower end of the zone of thermal neutrality. Below the critical temperature the animal's metabolic rate increases in response to thermoregulatory demand; above the critical temperature this demand is met by regulation of evaporative heat loss. For a given body size and thermal insulation, and under standardized conditions, a homoeotherm's critical temperature is determined by the level of feeding: as the amount of food the animal receives decreases, its critical temperature increases (Graham, Wainman, Blaxter \& Armstrong, I959; Close, Mount \& Start, I97I; Verstegen, Close, Start \& Mount, I973). It follows, therefore, that at the maintenance level of feeding the critical temperature would be expected to be below that of the fasting animal, and at higher levels of feeding the critical temperature would be even lower. Consequently, if fasting metabolism is measured at a temperature which corresponds to the critical temperature for the fed animal, a fasting metabolic rate higher than the minimum value may be obtained. Recognition of the interaction 
between temperature and the level of feeding is particularly important if efficiency of utilization of food for maintenance is to be determined, and if the fasting metabolism is to be used as a reference base for expressing metabolic rates at different levels of feeding as multiples of the fasting rate.

In the work reported in this paper, fasting heat loss has been measured in the growing pig maintained at two environmental temperatures and at two levels of feeding before fasting, in an attempt to determine from continuous $24 \mathrm{~h}$ measurements the fasting metabolic rate within the zone of thermal neutrality. A preliminary account of this work has been published (Close \& Mount, 1975).

\section{MATERIALS AND METHODS}

\section{Animals}

The animals, all castrated males, came from the Institute herd of Large White pigs which have been maintained free of enzootic pneumonia. The piglets were castrated at 3 weeks of age and weaned at 6 weeks of age; they had access to creep feed from I week of age. The animals were taken from the herd at io weeks of age and kept in groups in controlled environment pens until 2 weeks before the experiments.

\section{Plan of experiments}

Sixteen experiments were done and were designed in a $2 \times 2$ factorial arrangement involving two temperatures and two levels of feeding, i.e. four experiments at each temperature-level of feeding combination. The environmental temperature for each animal was maintained at either 20 or $3 \circ( \pm 0.5)^{\circ}$ throughout each experiment. At each temperature, the feeding level before and after a period of fasting was held at either 39 or $45 \mathrm{~g}$ food $/ \mathrm{kg}$ body-weight per $\mathrm{d}$. The four series of combinations of environmental temperature and feeding level were, therefore, $20^{\circ}-39 \mathrm{~g}$ (series $\mathrm{A}$ ), $20^{\circ}-45 \mathrm{~g}$ (series B), $30^{\circ}-39 \mathrm{~g}$ (series C) and $30^{\circ}-45 \mathrm{~g}$ (series D). Sixteen pigs were used in the experiments. Four pigs were given each treatment combination; food was withheld from three animals for a $4 \mathrm{~d}$ period during each experiment, and the fourth pig (control) was fed for the whole experimental period.

\section{Feeding}

The animals were given a commercial 'growers' diet which was analysed weekly for each experiment; the food supplied $\mathrm{I} 87( \pm 2) \mathrm{g}$ crude protein (nitrogen $\times 6 \cdot 25) / \mathrm{kg}$ dry matter (DM) and $14.6( \pm 0.3) \mathrm{MJ}$ metabolizable energy (ME) $/ \mathrm{kg}$ DM. The food was offered dry and was divided into equal feeds given morning and afternoon. Water was available $a d l i b$. whether the animals were fed or fasted. Food and water were kept at the same temperature as that of the calorimeter.

\section{Mobile pens}

The mobile pens in which the animals were kept throughout the conditioning and experimental periods were constructed of $2.45 \mathrm{~mm}$ mild steel angle covered with 22 swg galvanized steel sheet. Each pen measured $\mathrm{r} .45 \mathrm{~m} \times 0.86 \mathrm{~m} \times 0.84 \mathrm{~m}$ and was 
supported $0.25 \mathrm{~m}$ from the ground on castors to aid ease of movement. The pens were equipped with individual feeding and watering bowls and the base was tapered to allow run-off and collection of urine. Removable hardwood 'duck-boards' constituted the floor: these facilitated drainage and collection of excreta and cleaning of pens.

\section{Calorimetry}

Two calorimeters were in use simultaneously. They were based on the heat-sink design (Mount, Holmes, Start \& Legge, 1967) which was used in earlier experiments (Holmes \& Mount, 1967; Close et al. 197r; Verstegen et al. 1973). The internal dimensions were $2.03 \mathrm{~m} \times 1 \cdot 12 \mathrm{~m} \times \mathrm{I} \cdot 22 \mathrm{~m}$, and the calorimeters were in temperaturecontrolled rooms. At the beginning of the experimental period the mobile pen holding the pig was wheeled into the calorimeter, thereby avoiding the need to transfer the pig from one housing to another and thus making an additional habituation period unnecessary.

\section{Course of the experiments}

The time course was similar for all experiments. Each animal was put individually into a mobile pen, and was maintained at the experimental temperature and feeding level for 2 weeks before the period of calorimetric observation began. The mobile pen containing the pig was then wheeled into the calorimeter on a Wednesday morning, and recording of the animal's heat loss was begun. For the animals which were to be fasted, food was withheld during the following Monday, Tuesday, Wednesday and Thursday, and offered again on the Friday morning, that is $\mathrm{I} / 2 \mathrm{~h}$ after the last feed. Heat loss was measured continuously, and calculated as a consecutive series of mean 3 -hourly values (for a $24 \mathrm{~h}$ period) for a period of 2 weeks for twelve experiments and, to ensure that a sufficient post-fasting period had been observed, for a period of 3 weeks for four experiments. The succession of 3 -hourly rates of heat loss was interrupted only by weighing and cleaning three times/week.

\section{Other measurements}

In addition to the continuous measurements of heat loss, the animal's body-weight was recorded on Monday, Wednesday and Friday mornings, when the pig was transferred to a clean mobile pen. Water intake was recorded each morning and afternoon. In addition, energy balances were made simultaneously with the measurements of heat loss for eight experiments, in order to determine directly the metabolizable energy content of the food.

\section{RESULTS}

Heat loss. Heat loss decreased rapidly during the first day of fasting, and then more slowly during the subsequent $3 \mathrm{~d}$, so that the lowest values were recorded during the third and fourth days of fasting. As there was no difference between heat losses for the third and fourth days $(P>0.05)$, the fasting heat loss was determined as the mean value for these days. In Table $I$ the mean values for the rates of heat loss for the $3 \mathrm{~d}$ before fasting and for the last $2 \mathrm{~d}$ of the fast are given 'per animal' as the actual daily mean heat loss, and 'per $\mathrm{kg}^{\mathbf{0 . 7 5}}$ ' to standardize rates relative to body-weight. Fig. I 
Table I. Mean rates of heat loss for each of the experimental pigs for the $3 d$ before fasting and for the final $2 d$ of fasting

(These pigs were maintained at different environmental temperature-feeding level combinations, and fasted for a $4 \mathrm{~d}$ period within the $14 \mathrm{~d}$ experimental period, and values are given for the corresponding periods for pigs that were given the same treatment combinations but were fed for the whole $14 \mathrm{~d}$ experimental period (control). Mean values with their standard errors for nine observations (three pigs, $3 \mathrm{~d}$ ) for the $3 \mathrm{~d}$ before fasting and for six observations (three pigs, $2 \mathrm{~d}$ ) for the final $2 \mathrm{~d}$ of fasting)

\begin{tabular}{|c|c|c|c|c|c|c|c|c|}
\hline \multirow{3}{*}{$\begin{array}{l}\text { Expt } \\
\text { series }\end{array}$} & \multirow{3}{*}{$\begin{array}{l}\text { Environ- } \\
\text { mental } \\
\text { tempera- } \\
\text { ture } \\
\left({ }^{\circ}\right)\end{array}$} & \multirow{3}{*}{$\begin{array}{l}\text { Feeding } \\
\text { level } \\
\text { (g/kg } \\
\text { body-wt } \\
\text { per d) }\end{array}$} & \multirow[b]{3}{*}{ Pig no. } & \multirow{3}{*}{$\begin{array}{c}\text { Initial } \\
\text { body-wt* } \\
(\mathrm{kg})\end{array}$} & \multicolumn{4}{|c|}{ Mean rates of heat loss $(\mathrm{kJ} / \mathrm{d})$} \\
\hline & & & & & \multicolumn{2}{|c|}{$3 \mathrm{~d}$ before fasting } & \multicolumn{2}{|c|}{ Final $2 \mathrm{~d}$ of fast } \\
\hline & & & & & Total & per $\mathrm{kg}^{0.75}$ & Total & per $\mathrm{kg}^{0.75}$ \\
\hline A & 20 & 39 & $\begin{array}{l}\text { I } \\
2 \\
3 \\
\text { Mean } \pm \mathrm{SE} \text { (fasting) } \\
4 \text { (control, fed) }\end{array}$ & $\begin{array}{l}25 \cdot 4 \\
32 \cdot 2 \\
38 \cdot 7 \\
29 \cdot 4\end{array}$ & $\begin{array}{l}6360 \\
8976 \\
8976 \\
8184\end{array}$ & $\begin{array}{c}564 \\
665 \\
578 \\
602 \pm 16 \\
650\end{array}$ & $\begin{array}{l}4536 \\
6192 \\
6264\end{array}$ & $\begin{array}{c}415 \\
494 \\
434 \\
448 \pm \text { I9 } \\
658\end{array}$ \\
\hline $\mathbf{B}$ & 20 & 45 & $\begin{array}{l}\text { I } \\
2 \\
3 \\
\text { Mean } \pm S E \text { (fasting) } \\
4 \text { (control, fed) }\end{array}$ & $\begin{array}{l}26 \cdot 7 \\
32 \cdot 7 \\
33 \cdot 7 \\
34 \cdot 3\end{array}$ & $\begin{array}{l}7776 \\
8640 \\
9576 \\
9432\end{array}$ & $\begin{array}{c}662 \\
631 \\
686 \\
660 \pm \mathrm{x} 6 \\
66_{5}\end{array}$ & $\begin{array}{l}5280 \\
5808 \\
5880 \\
\\
9528\end{array}$ & $\begin{array}{c}490 \\
46 I \\
45 I \\
467 \pm 9 \\
63 I\end{array}$ \\
\hline $\mathrm{C}$ & 30 & 39 & $\begin{array}{l}\text { I } \\
2 \\
3 \\
\text { Mean } \pm \text { sE (fasting) } \\
4 \text { (control, fed) }\end{array}$ & $\begin{array}{l}28 \cdot 6 \\
35 \cdot 4 \\
37 \cdot 9 \\
32 \cdot 7\end{array}$ & $\begin{array}{r}8376 \\
8808 \\
10728 \\
9648\end{array}$ & $\begin{array}{c}677 \\
607 \\
701 \\
662 \pm 18 \\
706\end{array}$ & $\begin{array}{l}4416 \\
4752 \\
4896 \\
9312\end{array}$ & $\begin{array}{c}386 \\
356 \\
343 \\
362 \pm 12 \\
643\end{array}$ \\
\hline $\mathbf{D}$ & 30 & 45 & $\begin{array}{l}\text { I } \\
2 \\
3 \\
\text { Mean } \pm \mathrm{SE} \text { (fasting) } \\
4 \text { (control, fed) }\end{array}$ & $\begin{array}{l}29 \cdot 9 \\
34 \cdot 5 \\
36 \cdot 5\end{array}$ & $\begin{array}{r}8376 \\
11208 \\
11448 \\
10368\end{array}$ & $\begin{array}{c}655 \\
787 \\
770 \\
737 \pm 23 \\
785\end{array}$ & $\begin{array}{r}3912 \\
5880 \\
5736 \\
11280\end{array}$ & $\begin{array}{c}329 \\
449 \\
418 \\
399 \pm 25 \\
802\end{array}$ \\
\hline
\end{tabular}

* Mean values for the two weighings done immediately before fasting.

shows the actual rates of mean heat loss/h for pig no. 2 for 3 -hourly periods throughout the whole of the series $\mathrm{C}\left(30^{\circ}-39 \mathrm{~g}\right)$ experiment; the interruptions on Mondays, Wednesdays and Fridays were for cleaning and weighing. There was a clear 24-hourly variation; the reduction in the amplitude of the variation during fasting which is apparent in Fig. I was found also in other experiments. Fig. 2 shows the mean rates of heat loss, together with its 'sensible' and 'evaporative' components, for series A, B, $\mathrm{C}$ and $\mathrm{D}$ experiments, and in Fig. 3 the results are expressed, for each treatment combination, as a percentage of the initial heat loss (mean rates of heat loss for the $3 \mathrm{~d}$ before fasting).

There was, in general, good agreement between replicate values, although the body-weights of the animals in series A experiments differed by more than $10 \mathrm{~kg}$. When expressed as percentages of the mean values, the values for individual heat losses $\left(\mathrm{kJ} / \mathrm{kg}^{0.75}\right.$ per $\left.\mathrm{d}\right)$ for the prefasting period differed by less than $10 \%$. Values obtained for the fasting period only for the animals in series D experiments differed from the mean value by more than this amount.

Heat loss was influenced by both the environmental temperature and the level of 


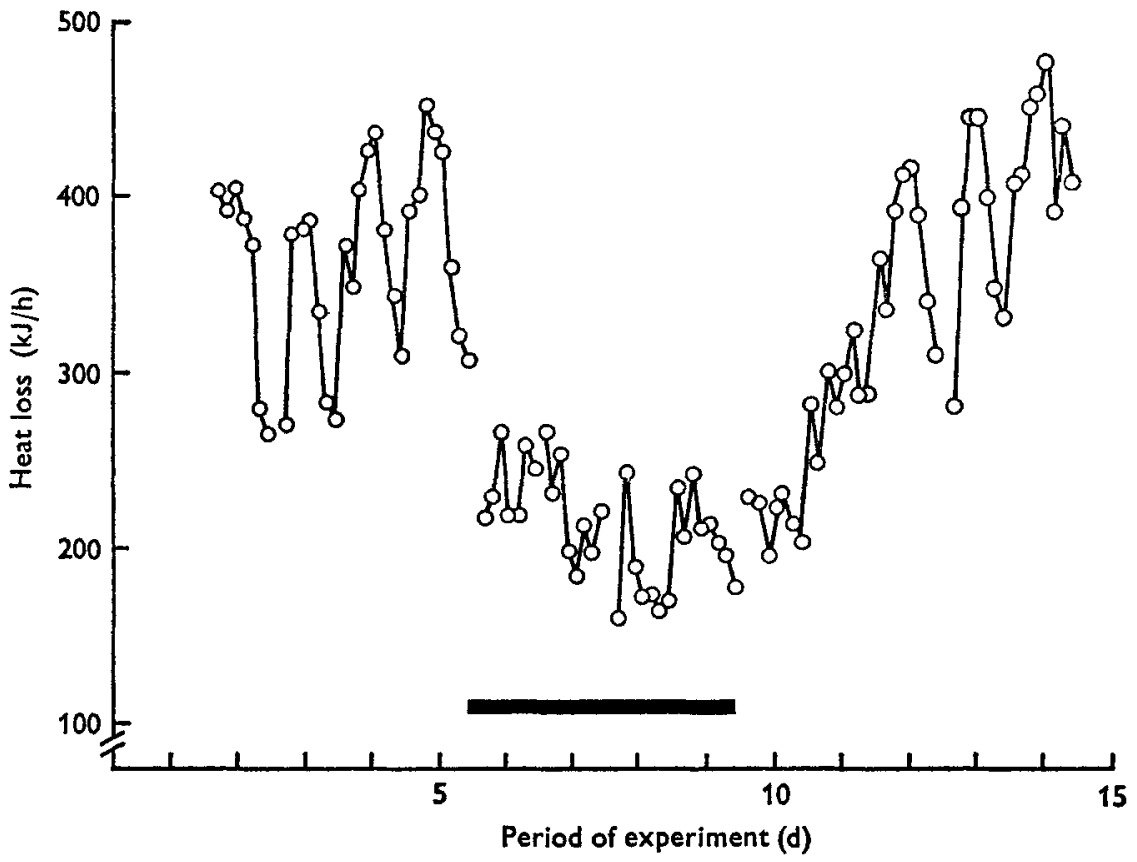

Fig. 1 . Pattern of heat loss $(\mathrm{kJ} / \mathrm{h})$ for pig no. 2 for $3 \mathrm{~h}$ periods throughout the $14 \mathrm{~d}$ experimental period when the animal was kept at an environmental temperature of $30^{\circ}$ and fed $39 \mathrm{~g}$ food $/ \mathrm{kg}$ body-wt per d with a $4 \mathrm{~d}$ fasting period within the $\mathrm{I} 4 \mathrm{~d}$ experimental period. in, Period of fasting.

feeding. The heat losses were significantly higher $(P<0.05)$ at the higher feeding levels, but heat losses during fasting were not significantly influenced by the preceding level of feeding $(P>0.05)$. During feeding the heat loss at $30^{\circ}$ was higher than that at $20^{\circ}(P<0.01)$; during fasting, heat losses at $20^{\circ}$ were higher than those at $30^{\circ}$ $(P<0.01)$. When expressed as a percentage of the mean heat loss in the prefasting period the mean values, with their standard errors, for the experimental pigs on the third and fourth days of fasting were: $74 \cdot 4 \pm \mathrm{I} \cdot 8$, series $A ; 70 \cdot 8 \pm 1 \cdot 8$, series $B$; $54 \cdot 8 \pm 2 \cdot 3$, series $C ; 53 \cdot 8 \pm 2 \cdot 0$, series D (see Fig. 3 ). In agreement with the absolute values, the proportionate values were significantly higher at $20^{\circ}$ than at $30^{\circ}(P<0.01)$.

On resumption of feeding, heat loss reached the prefasting levels by the third day (Figs. 2 and 3). Mean heat losses, with their standard errors, for the experimental pigs for the fourth and fifth days of refeeding were ( $\%$ prefasting levels): $98 \cdot 3 \pm 2 \cdot 6$, series $A ;$ IOI $5 \pm 6 \cdot 2$, series $B ; 100 \cdot 2 \pm 3 \cdot 3$, series $C ;$ IOI. $8 \pm 3 \cdot 4$, series $D$. The corresponding values for the control pigs were $105.7,102 \cdot 5,93.6$ and $101 \cdot 4$. These results suggested that a $5 \mathrm{~d}$ refeeding period was sufficient to study the changes in heat loss associated with refeeding. When measurements during refeeding were extended from 5 to $\mathrm{I} 2 \mathrm{~d}$, no additional changes were found.

Body-weight. The body-weight gain of the animals for the period before fasting and for the control experiments were similar to those found by Holmes \& Mount (1967), Close et al. (1971) and Verstegen et al. (1973). When fasting, the pigs lost an average of $10 \%$ of their body-weight during the first $2 \mathrm{~d}$ of fasting and a further $2-4 \%$ during 


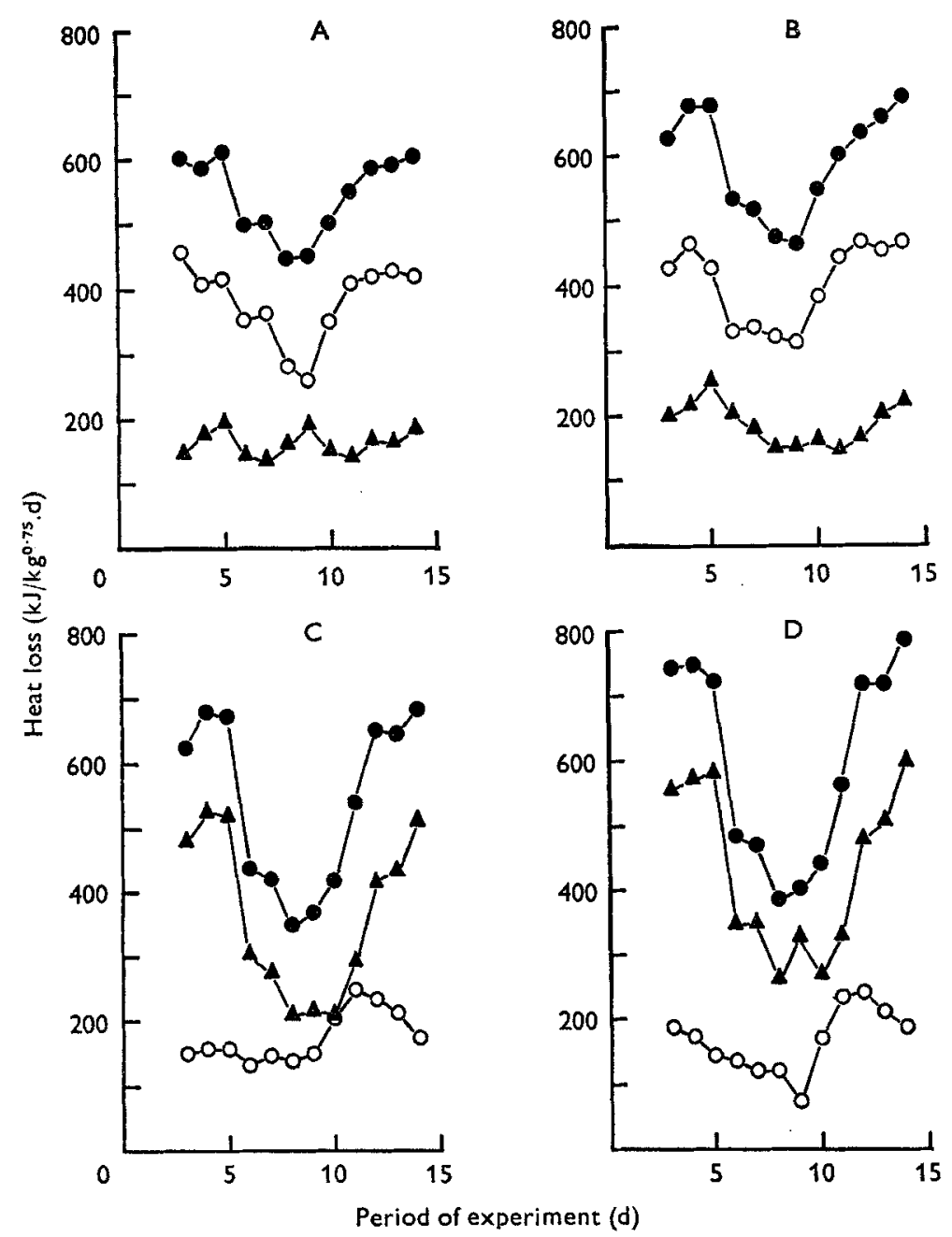

Fig. 2. Partition of heat loss ( $\mathrm{kJ} / \mathrm{kg}^{0.25}$ per $\mathrm{d}$ ) into 'sensible' and 'evaporative' components for pigs maintained on one of two levels of feeding ( 39 or $45 \mathrm{~g}$ food $/ \mathrm{kg}$ body-wt per $\mathrm{d}$ ) at environmental temperatures of 20 or $30^{\circ}$ for experimental periods of $14 \mathrm{~d}$, including a $4 \mathrm{~d}$ fasting period. - Total heat loss; $O-O$, sensible heat loss; $\Delta-\mathbf{A}$, evaporative heat loss; $\mathbf{A}$, $20^{\circ}-39 \mathrm{~g} ; \mathrm{B}, 20^{\circ}-45 \mathrm{~g} ; \mathrm{C}, 30^{\circ}-39 \mathrm{~g} ; \mathrm{D}, 30^{\circ}-45 \mathrm{~g}$. Mean values for three experimental pigs/ treatment.

the third and fourth days of fasting (Fig. 4). The mean total weight losses during fasting, with their standard errors, for the experimental pigs were $(\mathrm{kg}): 4 \cdot 00 \pm \mathrm{I} \cdot 10$, series $A ; 4.64 \pm 0.27$, series $B ; 4.64 \pm 0.33$, series $C ; 5.08 \pm 0.61$, series D. During the first half of the fasting period the weight losses appeared to be related to the animal's previous nutritional intake. For pigs maintained at the ' $39 \mathrm{~g}$ ' feeding level (series A and $C$ ) the weight losses were $I \cdot 63 \pm 0.35$ and $I .68 \pm 0.16 \mathrm{~kg} / \mathrm{d}$ respectively, and those for pigs maintained at the ' $45 \mathrm{~g}$ ' feeding level (series $B$ and $D$ ) were $I \cdot 75 \pm 0.18$ and $\mathrm{I} \cdot 78 \pm 0.20 \mathrm{~kg} / \mathrm{d}$ respectively. Temperature had an effect on the weight losses during the second half of the fasting period; the pigs maintained at $30^{\circ}$ lost more weight than those maintained at $20^{\circ}$. 


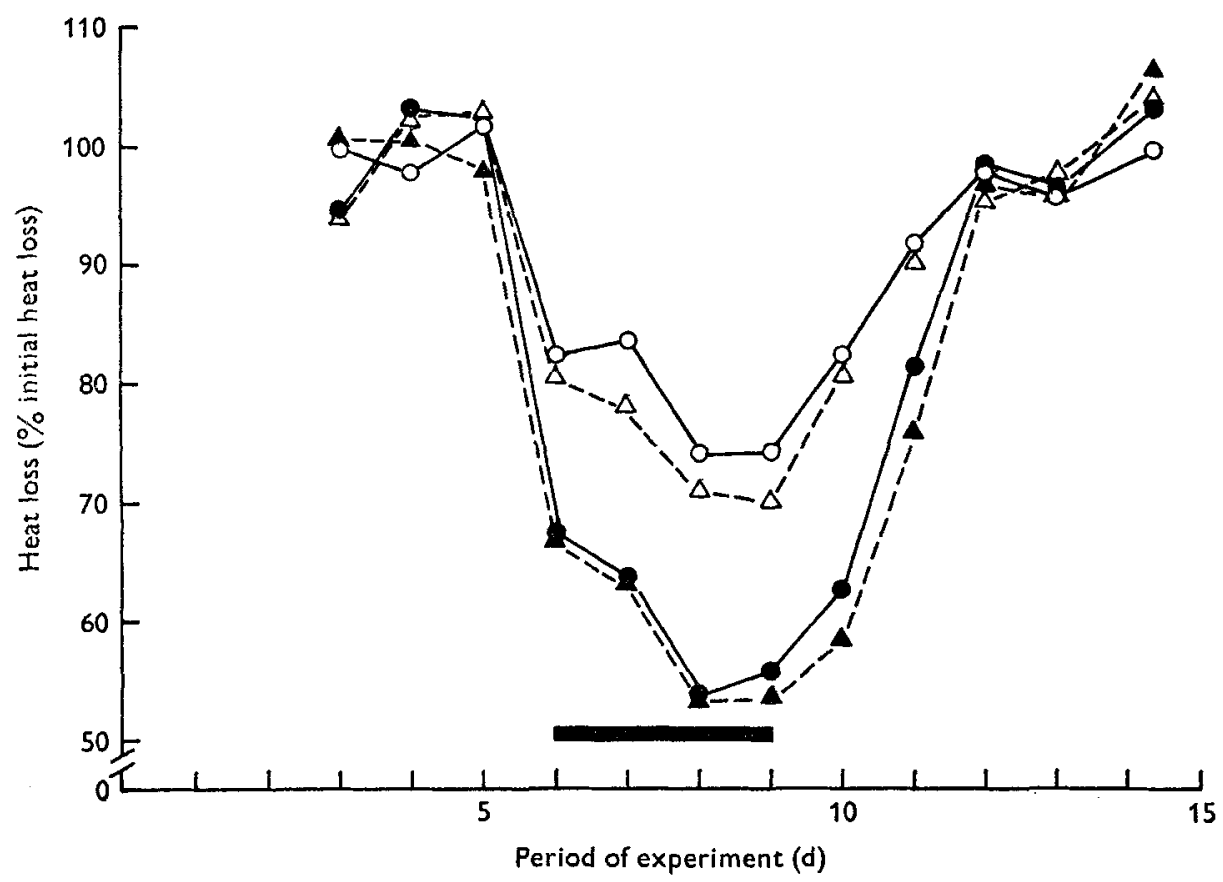

Fig. 3. Heat loss from pigs maintained on one of two levels of feeding ( 39 or $45 \mathrm{~g}$ food $/ \mathrm{kg}$ body-wt per d) and at environmental temperatures of 20 or $30^{\circ}$ for experimental periods of I $4 \mathrm{~d}$, including a $4 \mathrm{~d}$ fasting period; values are expressed as a percentage of the initial feeding heat loss (mean rate of heat loss for the $3 \mathrm{~d}$ before the fasting period) at these temperatures. $\bigcirc-O, 20^{\circ}-39 \mathrm{~g} ; \triangle--\triangle, 20^{\circ}-45 \mathrm{~g} ; 0-0,30^{\circ}-39 \mathrm{~g} ; \Delta--\Delta, 30^{\circ}-45 \mathrm{~g} ; \square$, period of fasting. Mean values for three experimental pigs/treatment.

On refeeding, all animals made rapid weight gains in the $3 \mathrm{~d}$ after fasting, reaching body-weights greater than those before fasting (see Fig. 4). The rate of gain varied between 1.59 and $2.08 \mathrm{~kg} / \mathrm{d}$. In the succeeding $2 \mathrm{~d}$ the weight gains were small; however, in the experiments lasting 3 weeks the values returned, between the eighth and twelfth day of refeeding, to the levels of the pre-fasting period.

Water intake. In the period before fasting, water intake (see Table 2) was within the ranges found both for groups of pigs and for individual pigs by Mount, Holmes, Close, Morrison \& Start (1971). During fasting, the mean water intakes were generally lower than those for the pre-fasting period. The only exception to this trend was pig no. 2 during series A experiments; its water intake was highest during the second half of the fasting period.

\section{DISCUSSION}

The reduction of heat loss to an apparent minimum on the third and fourth days of fasting is in agreement with the corresponding period of $72-110 \mathrm{~h}$ inferred from the results of Tangl (1912), Capstick \& Wood (I922), Breirem (1936, 1939) and Thorbek (1974). For sheep and cattle the corresponding period is $72-96 \mathrm{~h}$ (Blaxter, 1962; Blaxter \& Wainman, I966; Webster, Brockway \& Smith, 1974).

The decrease in heat loss during fasting occurred almost entirely in the 'sensible' 

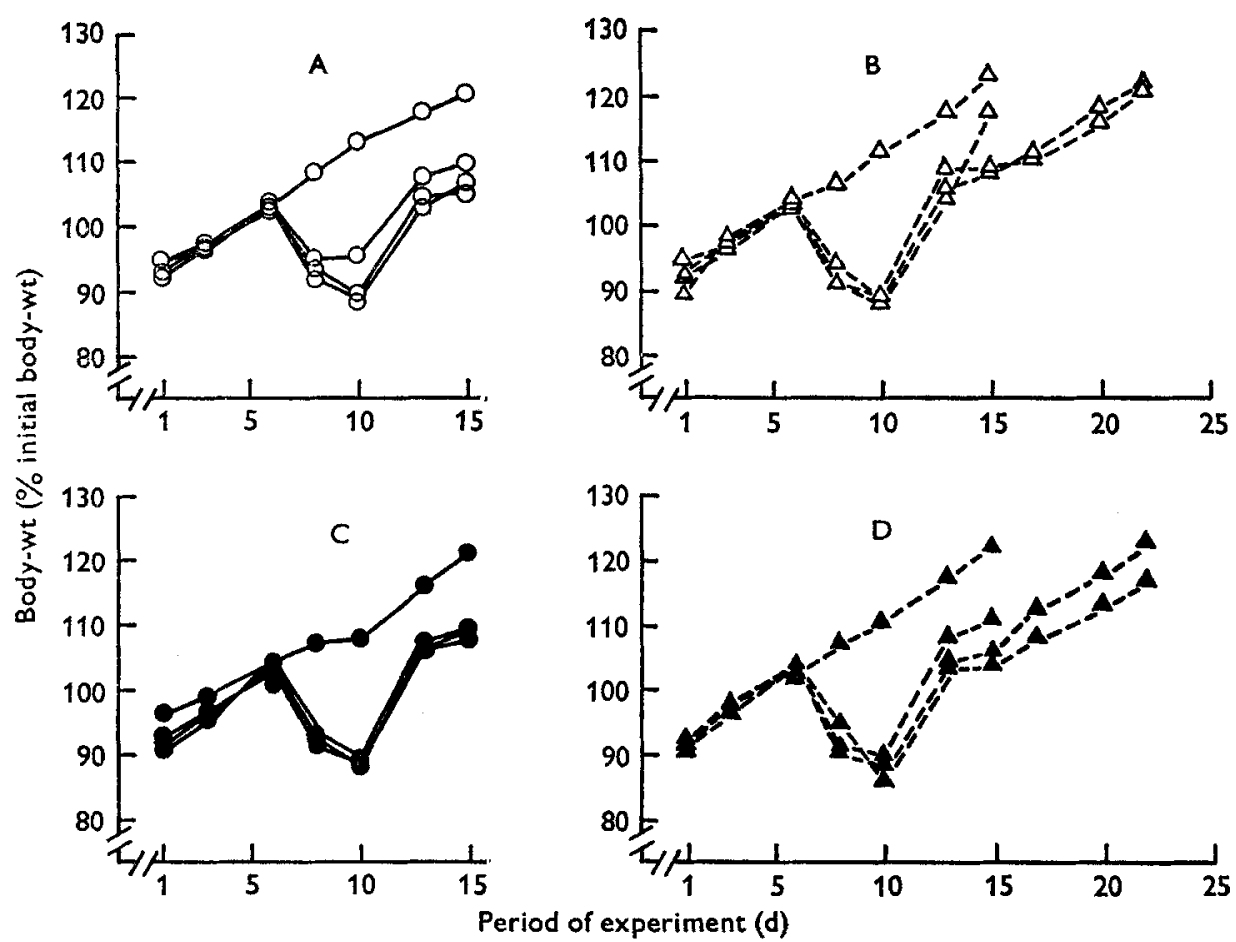

Fig. 4. Body-wt for pigs maintained on one of two levels of feeding ( 39 or $45 \mathrm{~g}$ food/kg body-wt per d) and at environmental temperatures of 20 or $30^{\circ}$ for experimental periods of 14 or $21 \mathrm{~d}$, including, for three pigs (experimental), a $4 \mathrm{~d}$ fasting period; values are expressed as a percentage of the mean body-wt during the initial period of feeding (pre-fasting) at these temperatures. A, $20^{\circ}-39 \mathrm{~g} ; \mathrm{B}, 20^{\circ}-45 \mathrm{~g} ; \mathrm{C}, 30^{\circ}-39 \mathrm{~g} ; \mathrm{D}, 30^{\circ}-45 \mathrm{~g}$. Individual values for three experimental pigs and one control pig (fed for the whole $14 \mathrm{~d}$ period)/treatment.

component at $20^{\circ}$ and in the 'evaporative' component at $30^{\circ}$; the mean values for each series of experiments are given in Table 3. Fig. 2 shows the changes which took place in the partition of heat loss during refeeding. The increase in heat loss at $20^{\circ}$ was entirely the result of an increase in the 'sensible' component. At $30^{\circ}$, there was an initial increase in the 'sensible' component, which was followed by a decrease when the evaporative loss increased. The increase in the evaporative loss was probably the consequence of a gradual decrease in the effective critical temperature. The higher levels of both evaporative and total heat losses for the ' $45 \mathrm{~g}$ ' feeding level were also in accordance with the lower critical temperature to be expected compared with that on the ' $39 \mathrm{~g}$ ' feeding level. The increase in the evaporative heat loss was accompanied by an increased water intake (see Table 2).

Although the feeding level preceding the fast did not influence the fasting metabolism, heat losses during the pre- and post-fasting periods were significantly related to the level of feeding at both temperatures. This suggested that the temperatures of 20 and $30^{\circ}$ were above the critical temperature when the animals were fed at either the ' $39 \mathrm{~g}$ ' or the ' $45 \mathrm{~g}$ ' feeding levels. Furthermore, heat losses at $30^{\circ}$ were higher than those at $20^{\circ}$, both absolutely (Fig. 2) and proportionately (Fig. 3), suggesting that $30^{\circ}$ 
Table 2. Mean rate of water intake ( $l / k g$ body-wt per $d$ ) for the experimental pigs for the periods before fasting, during fasting and after fasting

(These pigs were maintained at different environmental temperature-feeding level combinations, and fasted for a $4 \mathrm{~d}$ period within the $\mathrm{I} 4 \mathrm{~d}$ experimental period, and values for the corresponding periods for pigs that were given the same treatment combinations but were fed for the whole $\mathrm{I} 4 \mathrm{~d}$ experimental period (control) are supplied. Mean values for three experimental pigs/treatment; with one control pig/treatment)

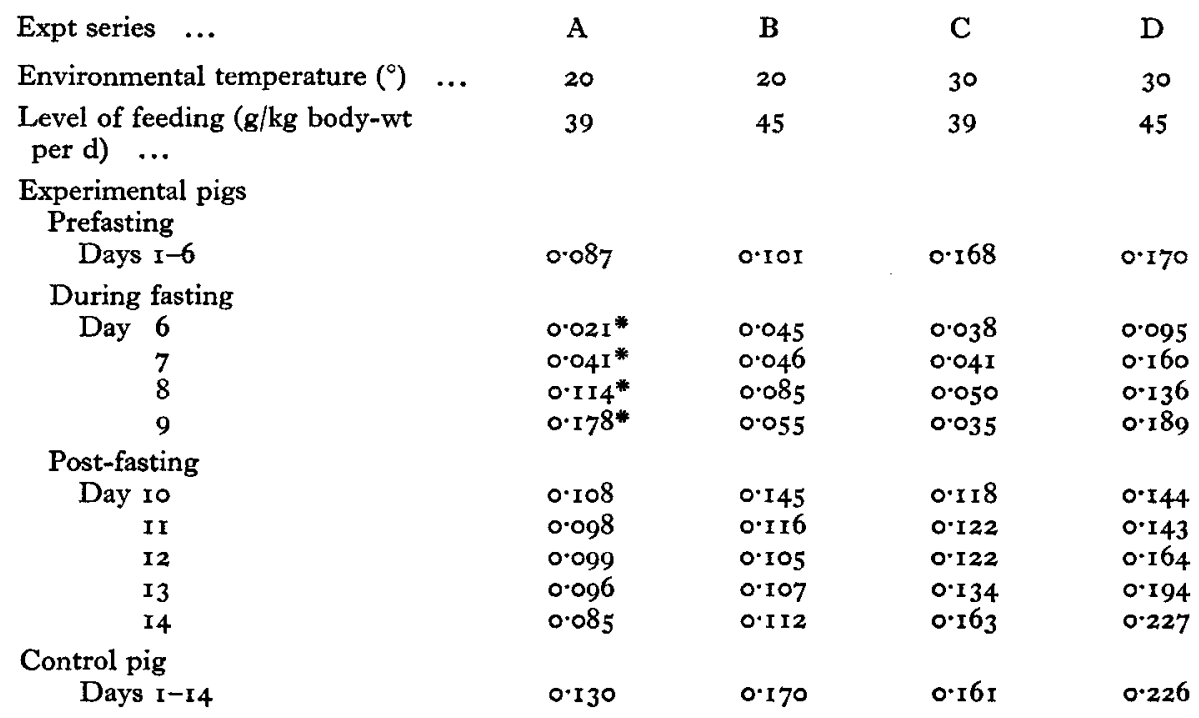

* The values include those for pig no. 2: excluding values for this pig, the mean values for the remaining two pigs were: $0.028,0.008,0.081,0.063 \mathrm{l} / \mathrm{kg}$ body-wt for days $6,7,8,9$ respectively.

Table 3. The mean rates of sensible and evaporative heat losses $\left(k^{7} / \mathrm{kg}^{0.75} \mathrm{per} d\right)$ for the experimental pigs for the initial period of feeding (prefasting) and for the third and fourth days of fasting

(These pigs were maintained at an environmental temperature of 20 or $30^{\circ}$ and at one of two different levels of feeding, and fasted for a $4 \mathrm{~d}$ period within the $14 \mathrm{~d}$ experimental period. Mean values with their standard errors for three pigs/treatment for both feeding and fasting periods)

\begin{tabular}{|c|c|c|c|c|c|c|c|}
\hline \multirow{3}{*}{$\begin{array}{l}\text { Expt } \\
\text { series }\end{array}$} & \multirow{3}{*}{$\begin{array}{c}\text { Environmental } \\
\text { temperature } \\
\left(^{\circ}\right)\end{array}$} & \multirow{3}{*}{\multicolumn{2}{|c|}{$\begin{array}{c}\begin{array}{c}\text { Feeding } \\
\text { level }\end{array} \\
(\mathrm{g} / \mathrm{kg} \text { body-wt per } \mathrm{d})\end{array}$}} & \multirow{2}{*}{\multicolumn{2}{|c|}{ Sensible }} & & \\
\hline & & & & & & \multicolumn{2}{|c|}{ Evaporative } \\
\hline & & & & Mean & SE & Mean & SE \\
\hline \multirow[t]{2}{*}{ A } & 20 & 39 & Feeding & 427 & I 5 & I75 & IO \\
\hline & & & Fasting & 271 & I 5 & 179 & II \\
\hline \multirow[t]{2}{*}{ B } & 20 & 45 & Feeding & $43^{8}$ & 17 & 223 & IO \\
\hline & & & Fasting & 316 & 16 & I5I & 21 \\
\hline \multirow[t]{2}{*}{ C } & 30 & 39 & Feeding & 154 & I8 & 509 & 9 \\
\hline & & & Fasting & 145 & I0 & 213 & I3 \\
\hline \multirow[t]{2}{*}{ D } & $3^{\circ}$ & 45 & Feeding & 168 & 25 & 570 & 10 \\
\hline & & & Fasting & 98 & $3^{8}$ & 300 & 29 \\
\hline
\end{tabular}


was in the hyperthermal zone. These suggestions are based on conclusions reached earlier, that when the environmental temperature is above the critical temperature the rate of heat loss is dependent on the level of feeding, whereas below the critical temperature the rate of heat loss is determined by the environmental temperature (Close et al. 1971; Verstegen et al. 1973).

The efficiency of utilization of $M E$ for maintenance $\left(\mathrm{k}_{\mathrm{m}}\right) . k_{m}$ can be expressed as the ratio, fasting heat loss or production:maintenance energy requirement of the animals, when both measurements are minimal, that is, determined within the zone of thermal neutrality. Taking the mean value of $475 \mathrm{~kJ} / \mathrm{kg}^{0 \cdot 75}$ per d referred to by Verstegen et al. (1973) as the maintenance energy requirement, and the thermoneutral fasting heat loss of $380 \mathrm{~kJ} / \mathrm{kg}^{0.75}$ per d determined in the present experiments (Table $\mathrm{I}$ ) the value obtained for $k_{m}$ is 0.80 . This value is similar to that of $0.8 \mathrm{I}$ determined by Breirem (1936). If the fasting heat loss below thermal neutrality at $20^{\circ}\left(45^{8} \mathrm{~kJ} / \mathrm{kg}^{0.75}\right.$ per d) is used instead of the thermoneutral value, then the apparent $k_{m}$ would have been 0.96 . This emphasizes the error that can result when either one or both measurements are not minimal.

Heat loss and body-weight. The use of $\mathrm{kg}^{0.75}$ has been generally accepted as a reference base for metabolic body size when expressing metabolic rate. The corresponding coefficients of body-weight for the present experiments can be calculated from the formula:

$$
H=a W^{b}, \text { i.e. } \log H=\log a+b \log W,
$$

where $H$ is the fasting heat loss $(\mathrm{kJ} / \mathrm{d})$ and $W$ is the fasting body-weight $(\mathrm{kg})$. Mean values, with their standard errors, for $a$ and $b$ for the fasting and feeding periods were:

Environmental temperature $\left({ }^{\circ}\right)$

20

30

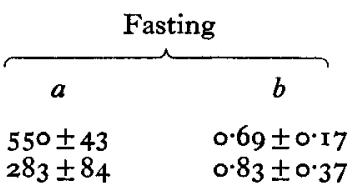

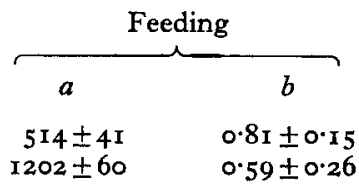

Values for $a$ for 20 and $30^{\circ}$ for the fasting period and for the feeding period were significantly different from each other $(P<0.01)$.

Values for $b$ for 20 and $30^{\circ}$ for the fasting period and for the feeding period were not significantly different from each other, or for the fasting period from the value of $0.75(P>0.05)$.

For each temperature the value for $b$ for the fasting period did not differ significantly $(P>0.05)$ from that for the feeding period. It may therefore be concluded that although there is not a specific exponent of body-weight which is precisely applicable in all instances, the use of $\mathrm{kg}^{0.75}$ is reasonable for the pig maintained at different feeding levels and environmental temperatures.

The present results indicate that young pigs have a higher fasting metabolism than that predicted from the mean interspecies value calculated by Kleiber (1932, 1961). The mean heat losses at 20 and $30^{\circ}\left(45^{8}\right.$ and $380 \mathrm{~kJ} / \mathrm{kg}^{0.75}$ per $\mathrm{d}$ respectively) were 156 and $130 \%$ respectively of that predicted from Kleiber's equation: $H=70 \mathrm{kcal}$ $(293 \mathrm{~kJ}) \mathrm{kg}^{0.75}$ per d. Blaxter (I962) and Blaxter \& Wainman (I966) concluded from their results that, relative to all species, sheep have a low fasting metabolism and 
Table 4. Values for the fasting heat losses for the pig maintained at various environmental temperatures, measured under different conditions

\begin{tabular}{|c|c|c|c|c|c|}
\hline \multirow[b]{2}{*}{$\begin{array}{l}\text { Body-wt } \\
\quad(\mathrm{kg})\end{array}$} & \multicolumn{4}{|c|}{ Conditions of measurements } & \multirow[b]{2}{*}{ Source } \\
\hline & $\begin{array}{c}\text { Environmental } \\
\text { temperature } \\
\left({ }^{\circ}\right)\end{array}$ & $\begin{array}{l}\text { Period after } \\
\text { last feed } \\
\text { (h) }\end{array}$ & $\begin{array}{c}\text { Period of } \\
\text { measurement }\end{array}$ & $\begin{array}{l}\text { Heat loss } \\
\left(\mathrm{kJ} / \mathbf{k g}^{0 \cdot 75}\right. \\
\text { per d) }\end{array}$ & \\
\hline $29-4 I$ & $16 \cdot 3$ & $96-120$ & & $5^{69}$ & Deighton (1923)* \\
\hline $25-40$ & $16 \cdot 3$ & $96-120$ & When asleep & 469 & Deighton (1929)* \\
\hline 105 & $16 \cdot 9$ & 114 & & 380 & $\begin{array}{l}\text { Capstick \& Wood } \\
(\mathrm{rg22})^{*}\end{array}$ \\
\hline $26-60$ & 18 & $96-I 44$ & $24 \mathrm{~h}$ (mean) & 478 & Thorbek (1974) \\
\hline $21-33$ & $18 \cdot 7$ & $96-120$ & When asleep & 434 & Deighton (1929)* \\
\hline $23-36$ & 20 & $64-110$ & $2,4 \mathrm{~h}$ (mean) & $45^{8}$ & Present results \\
\hline 170 & 23.7 & 84 & When asleep & 269 & $\begin{array}{l}\text { Capstick \& Wood } \\
\text { (I922)* }\end{array}$ \\
\hline $20-40$ & $24-25$ & $120-144$ & & $3^{60}$ & Breirem (1936) \\
\hline $26-60$ & 26 & $96-144$ & $24 \mathrm{~h}$ (mean) & 380 & Thorbeck (I 974) \\
\hline $25-35$ & 30 & $64-110$ & & 380 & Present results \\
\hline
\end{tabular}

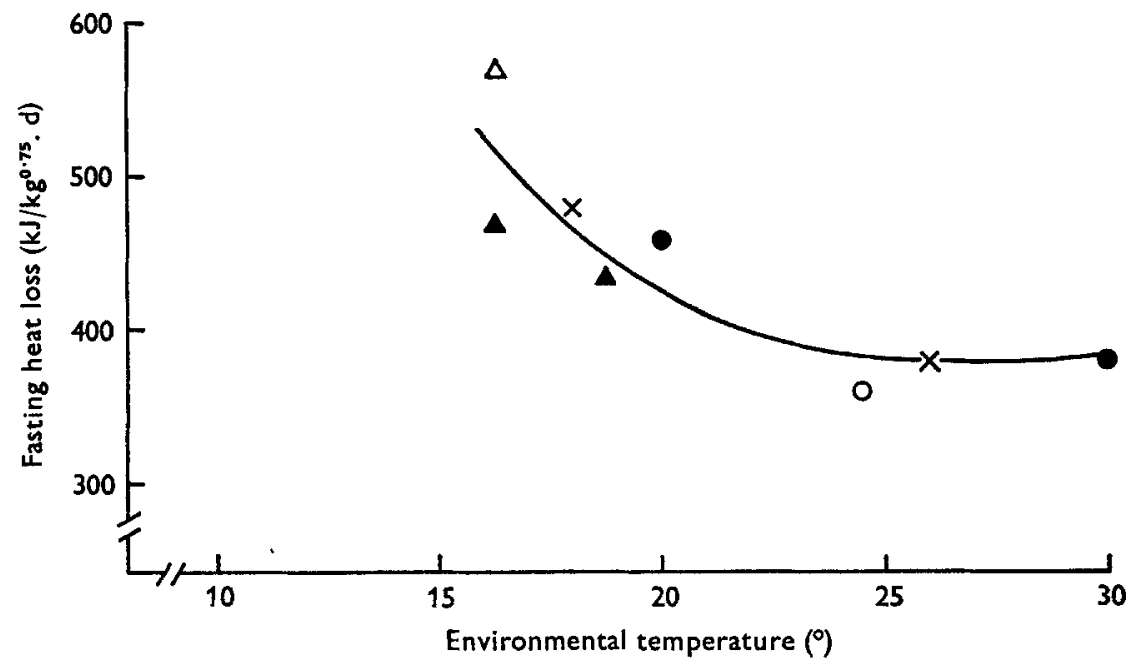

Fig. 5. Rates of fasting heat loss $\left(\mathrm{kJ} / \mathrm{kg}^{0.75}\right.$ per $\left.\mathrm{d}\right)$ for pigs maintained at various environmental temperatures $\left({ }^{\circ}\right.$ ), taken from several authors. 0 , Present results (mean values for six experimental pigs at each environmental temperature); $\times$, Thorbek (1974); $O$, Breirem (1936); $\triangle$, Deighton (r923); $\boldsymbol{\Delta}$, Deighton (r929).

cattle have a high fasting metabolism; for sheep it was $20 \%$ lower and for cattle it was $20 \%$ higher.

Other measurements of fasting metabolism: the determination of critical temperature. Although several studies have been done using fasted pigs in different laboratories, the variation in the conditions under which the measurements were made and the period of the fast make direct comparisons difficult. In the present experiments care was taken to avoid those sources of error which have been the subject of comment by van Es (1972): the mobile pens were large enough to offer no close restraint; habitu- 
ation to the condition of measurement was ensured by an adequate premeasurement period under similar conditions; measurements were made from a succession of $24 \mathrm{~h}$ periods, and not from isolated exposures. Using the mean value for the third and fourth days of fasting probably provides a better estimate of fasting metabolism than using only results from any $\mathrm{I} d$.

For the purposes of comparison a number of results have been collected (Table 4) in which the measurements were made at least $48 \mathrm{~h}$ after the last feed. Deighton (1923, I929) and Capstick \& Wood (1922) measured the heat loss for the animals only when they were asleep and not throughout the $24 \mathrm{~h}$ period. Their values have been converted to a mean 24 h rate by multiplying by $100 \div 83$, since it has been found in the present study that the heat loss during the period $00.00-09.00$ hours was $83 \%$ of that determined as the mean $24 \mathrm{~h}$ rate (see Fig. $\mathrm{r}$ ).

All results in Table 4 have been expressed per unit metabolic body size $\left(\mathrm{kg}^{0.75}\right)$ to reduce the variation resulting from the different body-weights of the animals. Although there is good agreement between results it is obvious that environmental temperature has a pronounced effect on the fasting metabolic rate. This is shown more clearly in Fig. 5, where values for the fasting heat losses for pigs similar in size to those used in the present work have been plotted $v$. environmental temperature. At temperatures above $25^{\circ}$, heat loss reaches a minimum, and therefore the probable effective critical temperature is $25^{\circ}$, and $30^{\circ}$ is within the zone of thermal neutrality. The conclusion is that determinations of the minimal fasting metabolism for individual pigs of this size should be made at a temperature not below $25^{\circ}$.

The authors thank Mr I. B. Start for the assistance which he provided throughout the experiments.

\section{REFERENCES}

Blaxter, K. L. (1962). Br. $尹$. Nutr. 16, 615.

Blaxter, K. L. \& Wainman, F. W. (1966). Br. F. Nutr. 20, to3.

Breirem, K. (1936). Tierernährung 8, 463 .

Breirem, K. (1939). Tierernährung Ix, 487 .

Capstick, J. W. \& Wood, T. B. (1922). F. agric. Sci., Camb. 12, 257.

Close, W. H. \& Mount, L. E. (r975). Proc. Nutr. Soc. 34, 13 A.

Close, W. H., Mount, L. E. \& Start, I. B. (r97r). Anim. Prod. 13, 285.

Deighton, T. (1923). Proc. R. Soc. B 95, 350.

Deighton, T. (1929). F. agric. Sci., Camb. 19, 140.

Graham, N. Mc. C., Wainman, F. W., Blaxter, K. L. \& Armstrong, D. G. (1959). Y. agric. Sci., Camb. 52, 13.

Holmes, C. W. \& Mount, L. E. (1967). Anim. Prod. 9, 435.

Kleiber, M. (1932). Hilgardia 6, 315.

Kleiber, M. (1961). The Fire of Life. New York: John Wiley \& Sons Ltd.

Mount, L. E., Holmes, C. W., Close, W. H., Morrison, S. R. \& Start, I. B. (I971). Anim. Prod. 13, 56 I. Mount, L. E., Holmes, C. W., Start, I. B. \& Legge, A. J. (1967). F. agric. Sci., Camb. 68, 47.

Tangl, F. (1912). Biochem. Z. 44, 252.

Thorbek, G. (1974). Publs Eur. Ass. Anim. Prod. no. 14, p. 147.

van Es, A. J. H. (1972). In Handbuch der Tierernährung, vol. 2, p. I [W. Lenkeit and K. Breirem, editors]. Berlin: Paul Parey.

Verstegen, M. W. A., Close, W. H., Start, I. B. \& Mount, L. E. (I973). Br. F. Nutr. 30, 2 r.

Webster, A. J. F., Brockway, J. M. \& Smith, J. S. (1974). Anim. Prod. I9, 127. 